referred to with equal facility. Apart from a final interest. ing chapter on mortality it sticks closely to the stated theme and adheres to its self imposed rules.

One hopes that in the nineteen-seventies more scholars in more fields will publish book-length syntheses of this type. If it does not happen, then even the best and most significant findings of original scholarship will fail to get into the textbooks. The gap between research and teaching will then have grown too wide to be bridged.

G. Malcolm Lewis

\section{ONE MAN'S CONTRIBUTION}

The Transmission of Passive Immunity from Mother to Young

By F. W. Rogers Brambell. (North-Holland Research Monographs-Frontiers of Biology, Vol. 18.) Pp. xvi+ 385. (North-Holland: Amsterdam and London, 1970.) Hfl. $65 ; 152 s ; \$ 18.20$.

WIтH the death of Professor Brambell developmental biology has lost one of its finest and most respected mentors. The publication of this volume at such a sad time was coincidental but perhaps appropriate. In it, his most important contribution to our knowledge of the acquisition of humoral immunity by the foetus and newborn is extensively described with characteristic thoroughness and lucidity. Published as one in a series of excellent monographs it presents a systematic examination of both prenatal and postnatal transmission of maternal antibodies to the young in a variety of species.

The writing of a monograph has unfortunately become one more hurdle in a scientist's career, something that one is expected to do. As a result the average reader is bombarded by expensive prestige books often of the very lowest intellectual quality, shrapnel in the information explosion. Professor Brambell's book is most certainly not one of them. It is simply an excellent review and summary of one man's contribution to his subject. The quality of the book lies in the very high standard of experimentation presented, in the clear exposition of theory, and in the intellect of the author.

For each species there is a detailed account of placentation and the structure of the foetal membranes, followed by an elegant analysis of the mode of transfer of antibodies both before and after birth. The species examined include birds, marsupials, rodents, the cat, the dog, the hedgehog, ruminants, the pig and, finally, monkeys and man. One splendid chapter considers the association between the transmission of antibodies and haemolytic disease of the newborn in many species and ends with an intriguing paradox; the absence of hremolytic disease in newborn ruminants. Experimental immunization studies show the development of the appropriate antibodies and their subsequent transmission to the young through the colostrum. Such antibodies are haemolytic in vitro and yet the young are unaffected.

The final section is an erudite collection of conclusions and hypotheses. With its emphasis on the selective transmission of antibody and the probable presence of specific globulin receptor sites on cells it clearly outlines the resemblances between antibody transmission and anaphylactic sensitization. How can a complex protein like antibody globulin survive its passage through a cell packed with proteolytic enzymes? Professor Brambell argues with conviction that specific receptors bind to the globulin and inhibit enzyme digestion within the phagosomes. Saturation of these receptors causes excess globulins to be degraded; a simple yet elegant theory amply supported by experimental evidence. Indeed, most statements made in this book are backed by abun. dant evidence. Forty-two pages of references may seem excessive in some books. In this one they are an integral and vital part.

The price of this volume will no doubt limit it to the shelves of institute libraries and a few well-heeled developmental immunologists. It is no doubt a book for the specialist in spite of its obvious relevance to practical clinical problems. To one reviewer at least it is a source of delight and an excellent reminder of the qualities of the late Professor Brambell.

G. A. Currie

\section{LIVELY EMBRYOLOGY}

\section{Cells Into Organs}

The Forces that shape the Embryo. By J. P. Trinkaus. (Foundations of Developmental Biology Series.) Pp. xvi+237. (Prentice-Hall: New Jersey and Hemel Hempstead, 1969.) n.p.

EARLY students of cell behaviour in morphogenesis were, of course, well aware of the possible roles of change in cell size and cell shape. But they undervalued cell movements and were often over impressed by the importance of differential activity. We owe to Wilson, Vogt, Pasteels and Holtfreter the first development of a fresh approach the outcome of which is very well surveyed in Dr Trinkaus's book. It is noteworthy that he hardly has occasion to mention cell division and that when he does it is without exaggerated respect. Nevertheless, it is fair to suspect that it will return to a qualified favour in the future-not as solely responsible for any morphogenetic change, but as an important participant in some.

At the present time the parameters of cell behaviour most intensively studied are the strength and specificity of inter-cell adhesions, the modes of cell motility, and the social behaviour of cells the properties of which may depend critically on the company they keep. In each case the part of the cell most immediately involved is its surface. In each case a combination of in vivo and in vitro work on living cells must be supplemented by fine structural study and chemical analysis. Already some seemingly complex pieces of morphogenetic activity promise to yield to analysis in fairly simple terms.

Trinkaus provides a good, and much needed, account of this lively field. It will serve equally as a primer of cell biology for embryologists and of morphogenesis for cell biologists. He draws on a very wide range of material and is helpful in making clear the nature of contemporary disagreements. He is, however, more than clear; he succeeds in conveying real enthusiasm for the problems he describes.

D. R. NEWTH

\section{PICTORIAL ULTRASTRUCTURE}

\section{Cells and Tissues by Light and Electron Microscopy}

Vol. 1: Microscopie Photonique et Electronique de Tissus et de Cellules. English version by Edmund B. Sandborn, French by R. Gagnon, P. Jean and B. Messier. Pp. xiii +366. (Academic: New York and London, March 1970.) 135s.

ATLASES of ultrastructure are now commonplace and any new contribution has to offer something special to compete. This work is larger than most; it is, in fact, the first of two volumes and deals with the cell and basic tissues such as epithelia, muscle, nerve, connective tissue and lymphoid organs. Volume two will cover other systems such as endocrines, circulation, digestion, excretion, and the like. The special feature one is led to expect from the publisher's leaflets and from the dust cover is a thorough correlation of light and electron microscopy. It is claimed that the book "is a coordinated study of animal cells and tissues as seen in the light and electron microscope. . . . It is the first attempt at providing a study of biological structure which includes both light and electron microscopy". From this one might expect a careful comparison between the histology and histochemistry of a tissue and its ultrastructure. This is something that is lacking in the literature and it would be extremely valuable. This 